\title{
Metode Drill untuk Meningkatkan Hasil Belajar Matematika pada Siswa Kelas IV SD
}

\section{Made Suardiana ${ }^{1 *}$ \\ ${ }^{1}$ SD Negeri 1 Telaga Singaraja, Indonesia}

\section{A R T I C L E I N F O}

Article history:

Received July 16, 2021

Revised July 20, 2021

Accepted October 20, 2021

Available online November 25, 2021

Kata Kunci:

Metode Drill, Hasil Belajar.

Keywords:

Drill Method, Learning Outcomes

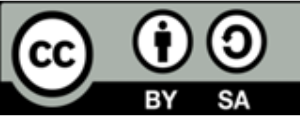

This is an open access article under the CC BY-SA license.

Copyright $(2021$ by Author. Published by Universitas Pendidikan Ganesha.

\begin{abstract}
A B S T R A K
Pengajaran matematika secara konvensional mengakibatkan siswa bekerja secara prosedural dan memahami matematika tanpa penalaran, Selain itu, interaksi antara siswa selama proses belajar mengajar sangat kurang, sehingga mengakibatkan hasil belajar rendah. Penelitian ini bertujuan meningkatkan hasil belajar Matematika melalui penerapan metode drill pada siswa kelas IV SD. Jenis penelitian ini adalah penelitian tindakan kelas yang melibatkan siswa kelas IV yang berjumlah 10 orang siswa. Metode pengumpulan data menggunakan tes. Metode analisis data menggunakan analisis deskriptif. Hasil penelitian ini menunjukkan bahwa terjadi perbedaan hasil belajar antara siklus I (jumlah 645, rata-rata 65, daya serap $65 \%$, ketuntasan belajar $60 \%$ ) dan siklus II (jumlah 720, rata-rata 72 , daya serap $72 \%$, ketuntasan belajar $100 \%$ ). Terjadi peningkatan hasil belajar dari siklus I ke siklus II, yaitu terjadi kenaikan rata-rata daya serap $7 \%$ dan pada ketuntasan belajar mengalami kenaikan sebesar $40 \%$. Jadi, penerapan metode d matem rill pada siswa kelas IV SD dapat meningkatkan hasil belajar Matematika. Implikasi penelitian ini diharapkan dapat membantu siswa dalam proses pembelajaran, sehingga dapat meningkatkan hasil belajar matematika siswa.
\end{abstract}

\section{A B S T R A C T}

Conventional mathematics teaching causes students to work procedurally and understand mathematics without reasoning. Besides that, the interaction between students during the teaching and learning process is lacking, causing low learning outcomes. This study aims to improve mathematics learning outcomes by applying the drill method to fourth-grade elementary school students. This type of research is classroom action research involving ten students in grade IV. Methods of data collection using tests. Method of data analysis with descriptive analysis. The results of this study indicate that there is a difference in learning outcomes between cycle I (amount of 645, average of 65, absorption of 65\%, mastery of learning 60\%) and cycle II (amount of 720, average of 72, absorption of $72 \%$, mastery of learning $100 \%$ ). There was an increase in learning outcomes between cycle I and cycle II, showing an average increase in absorption of $7 \%$ and learning completeness an increase of $40 \%$. Thus, applying the drill method to fourth-grade elementary school students can improve learning outcomes. The implications of this research are expected to help students in the learning process to improve students' mathematics learning outcomes.

\section{PENDAHULUAN}

Belajar matematika pada hakikatnya adalah melakukan kegiatan mental. Dalam pembelajaran matematika, siswa dituntut mempersiapkan mental dalam proses penerimaan pengetahuan baru (Khairani \& Roza, 2021; Pambudi, 2007; Prasojo, 2016). Oleh karena itu, dalam mengajar matematika guru hendaknya menciptakan suasana yang menyenangkan, sehingga dapat mencapai hasil yang diinginkan. Setiap guru dituntut untuk meningkatkan kompetensi siswanya dalam setiap pembelajaran. Pada dasarnya, tujuan guru mengajar adalah untuk mengadakan perubahan yang dikehendaki dalam tingkah laku siswa (Crismono, 2017; Khaerunnisa \& Pamungkas, 2018; Prasasti et al., 2019). Dalam upaya meningkatkan proses dan hasil belajar, guru dan siswa sangat berperan penting .Oleh karena itu, guru harus berupaya menciptakan strategi yang cocok sebab dalam proses belajar mengajar yang bermakna, 
keterlibatan siswa sangat penting (Khairani \& Roza, 2021). Pada jenjang, sekolah dasar perlu diupayakan agar matematika betul-betul dikuasai dengan baik oleh siswa (Unaenah et al., 2020). Hal ini sangatlah logis mengingat Matematika memiliki hubungan yang sifatnya hirarkis. Matematika di jenjang sekolah dasar merupakan dasar atau pondasi yang amat penting untuk mempelajari matematika pada jenjang selanjutnya (Arianti et al., 2019; Unaenah et al., 2020). Pelaksanaan pembelajaran matematika juga dimulai dari yang sederhana ke kompleks. Matematika mempelajari semacam pola keteraturan tentang struktur yang terorganisasikan (Buyung \& Nirawati, 2018; Muhammad, 2020). Konsep-konsep tersusun secara hirarki, terstruktur, logis dan sistematis mulai dari konsep yang sederhana sampai pada konsep yang paling kompleks.

Matematika terdapat topik atau konsep prasyarat sebagai dasar untuk memahami topik atau konsep selanjutnya (Alfiyah et al., 2021; Pambudi, 2007). Dengan demikian, dalam mempelajari matematika, konsep sebelumnya harus benar-benar dikuasai untuk dapat memahami konsep-konsep selanjutnya (Dini et al., 2018; Sulastri, 2016). Hal ini tentu saja membawa akibat kepada terjadinya proses belajar-mengajar atau pembelajaran matematika. Oleh karena itu, dalam pembelajaran matematika tidak dapat dilakukan secara lompat-lompat. Pembelajarannya harus tahap demi tahap mulai dari pemahaman ide dan konsep yang sederhana sampai kejenjang yang lebih kompleks. Seseorang tidak mungkin mempelajari konsep yang lebih tinggi sebelum ia menguasai konsep yang lebih rendah (Netriwati, 2018; Ningsih, 2016). Hal ini merupakan tantangan yang dihadapi oleh guru untuk menjadikan matematika sebagai sesuatu yang menarik. Untuk itu guru dituntut menciptakan kegiatan yang menyebabkan siswa senang dan asyik dalam mempelajari matematika. Menciptakan suasana santai saat belajar dapat dilakukan guna untuk meningkatkan hasil belajar siswa. Salah satu kegiatan yang membuat siswa berperilaku dan berada dalam suasana di atas adalah melalui penerapan model pembelajaran yang inovatif (Kusumah et al., 2020; Yanni, 2018). Kenyataan dalam pelaksanaanya tugas utama guru itu kadang tidak terlaksana dengan sempurna. Ketika hasil tes siswa masih banyak yang harus remedial, maka seorang guru akan merasa dirinya gagal dalam mengajar Matematika. Dari pembelajaran awal yang dilaksanakan pada tanggal 9 Agustus 2019 pada 10 siswa kelas IV SD Negeri 2 Telaga, menunjukkan bahwa rata-rata hasil belajar sebesar 54, hasil belajar matematika tersebut masih rendah. Tingkat ketuntasan belajar (siswa memperoleh nilai minimal 70) hanya 30\% saja, sedangkan yang diharapkan sebesar 85\%. Padahal Kriteria Belajar Minimum (KBM) untuk mata pelajaran Matematika di kelas IV SD Negeri 2 Telaga adalah 70. Hal ini menunjukkan target yang dicapai guru belum terpenuhi. Lemahnya pemahaman siswa tersebut dilatarbelakangi oleh berbagai sebab, antara lain: pembelajaran matematika di sekolah masih menggunakan pendekatan tradisional atau konvensional yakni ceramah, pemberian tugas, pembelajarannya didominasi oleh guru dan sedikit sekali melibatkan siswa. Pada pembelajaran matematika di kelas, guru kurang memberikan kesempatan kepada siswa untuk mengonstruksi sendiri konsep-konsep matematika. Siswa hanya menyalin apa yang dikerjakan oleh guru. Selain itu, siswa tidak diberikan kesempatan untuk mengemukakan ide dan mengonstruksi sendiri dalam menjawab soal latihan yang diberikan oleh guru. Dengan metode tersebut, konsep materi tidak tertanam pada siswa. Oleh karean itu, guru harus mengulang materi pada pembelajaran berikutnya. Hal tersebut mengakibatkan banyak waktu yang dihabiskan untuk mengajarkan satu materi. Pengajaran matematika secara konvensional mengakibatkan siswa bekerja secara prosedural dan memahami matematika tanpa penalaran. Selain itu, interaksi antara siswa selama proses belajar mengajar sangat kurang.

Solusi yang dapat diterapkan guru untuk mengatasi permasalahan tersebut yaitu dengan menggunakan metode pembelajaran. Guru dapat menerapkan metode drill. Metode drill merupakan satu kegiatan melakukan hal yang sama, berulang-ulang secara sungguh-sungguh dengan tujuan untuk memperkuat suatu asosiasi atau menyempurnakan suatu ketrampilan agar menjadi bersifat permanen (Fransiska et al., 2019; Jauhariyah \& Dardiri, 2017; Putri et al., 2019). Drill merupakan sebuah metode yang membutuhkan skill dan penguasaan yang cukup tinggi, maka guru sebelumnya memberikan latihan haruslah lebih siap terlebih dahulu baik dari segi materi dan soal-soal yang akan dilatihkan, tidak secara spontanitas saja memberi latihan (Erlinda, 2016; Jaelani \& Aisyah, 2017). Waktu mengadakan evaluasi terhadap hasil latihan segera guru dapat melihat segi-segi kemajuan anak didik, di antaranya: daya tangkap, keterampilan, dan ketepatan berfikir dari tiap-tiap anak didik yang diberi tugas latihan (Fransiska et al., 2019; Jaelani \& Aisyah, 2017). Metode ini memiliki keunggulan sebagi berikut. 1) Bahan pelajaran yang diberikan dalam suasana yang sungguh-sungguh akan lebih kokoh tertanam dalam daya ingatan murid karena seluruh pikiran, perasaan, kemauan dikonsentrasikan pada pelajaran yang dilatihkan; (2) Anak didik akan dapat mempergunakan daya pikirannya dengan bertambah baikkarena dengan pengajaran yang baik maka anak didik akan menjadi lebih teratur, teliti dan mendorong daya ingatnya; (3) Adanya pengawasan, bimbingan dan koreksi yang segera serta langsung dari guru, memungkinkan murid untuk melakukan perbaikan kesalahan saat itu juga (Dewi et al., 2020). Hal ini dapat menghemat waktu belajar. Di samping itu, murid langsung mengetahui prestasinya. 
Beberapa temuan sebelumnya menyatakan metode drill dapat digunakan untuk meningkatkan kemampuan menulis permulaan bagi siswa (Natalita et al., 2019; Putri et al., 2019). Metode drill juga memberikan pengaruh terhadap hasil belajar siswa (Jauhariyah \& Dardiri, 2017).Melalui metode drill dapat menganalisis kemampuan pemecahan masalah siswa (Fransiska et al., 2019). Metode dril dapat meningkatkan hasil belajar matematika (Jaelani \& Aisyah, 2017, 2017). Penelitian terkait metode drill sudah pernah dilaksanakan, namun dalam penelitian ini metode drill diterapkan pada siswa kelas IV SD Negeri 2 Telaga. Tujuan penelitian tindakan kelas ini adalah untuk meningkatkan hasil belajar Matematika melalui penerapan metode drill. Penelitian diharapkan dapat mengatasi masalah yang serupa pada kelompok siswa yang lain. Selain itu, dapat menghilangkan kejenuhan siswa dalam belajar matematika dan dapat menarik minat siswa untuk belajar ,sehingga dapat meningkatkan hasil belajar siswa.

\section{METODE}

Penelitian ini menggunakan jenis penelitian tindakan kelas yang berdasarkan konsep penelitian tindakan Kemmis dan Mc.Targgat yang berbentuk siklus penelitian. Penelitian ini dilaksanakan di SD Negeri 2 Telaga dengan alamat Banjar Dinas Kumuda Loka Desa Telaga Kecamatan Busungbiu Kabupaten Buleleng. Penelitian ini dilaksanakan pada semester I tahun pelajaran 2019/2020 selama 4 bulan dari bulan Juli sampai dengan Oktober 2019. Subjek penelitian ini adalah siswa kelas IV yang berjumlah 10 orang, terdiri dari 6 orang laki-laki dan 4 orang perempuan. Penelitian yang dilakukan termasuk penelitian tindakan kelas. Oleh karenanya, rancangan yang khusus untuk sebuah penelitian tindakan sangat diperlukan. Penelitian tindakan didasarkan pada filosofi bahwa setiap manusia tidak suka atas halhal yang statis, tetapi selalu menginginkan sesuatu yang lebih baik. Peningkatan diri untuk hal yang lebih baik ini dilakukan terus menerus sampai tujuan tercapai (Arikunto, 2010). Rancangan penelitian tindakan kelas yang mengacu pada gagasan Kemmis dan Mc Taggart seperti terlihat pada Gambar 1.

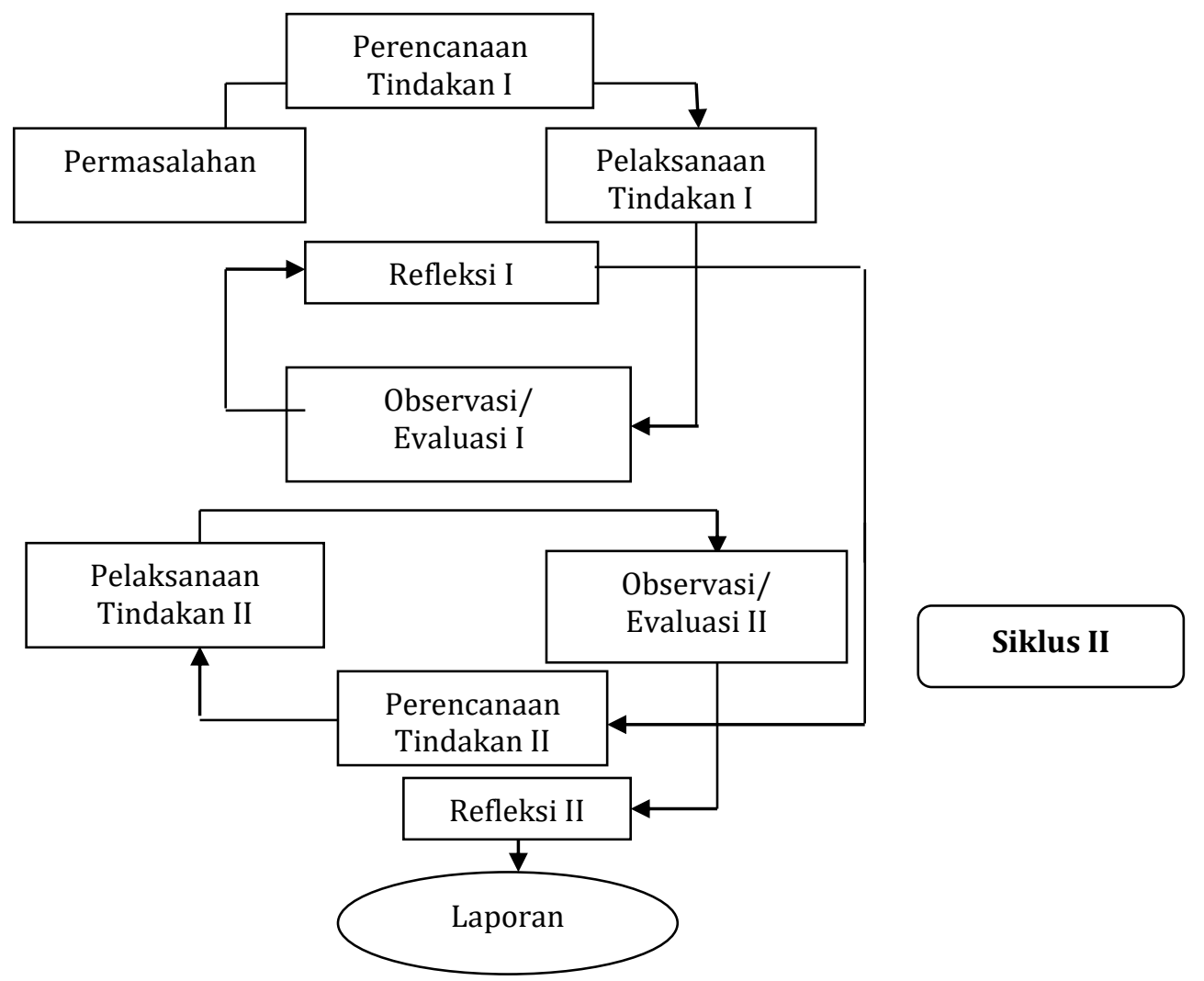

Gambar 1. Model Penelitian Kemmis dan Mc Taggart

Penelitian tindakan kelas ini dilaksanakan sesuai dengan rancangan penelitian seperti pada gambar di atas. Penelitian ini dimulai dari permasalahan yang ditemui oleh guru, permasalahanpermasalahan tersebut dikhawatirkan memberikan pengaruh yang kurang baik terhadap hasil belajar siswa sehingga tujuan pembelajaran tidak tercapai. Dengan indikator yang terlihat, maka hal tersebut dapat dijadikan dasar untuk membuat suatu rencana tindakan I untuk memperbaiki keadaan tersebut dengan menerapkan pembelajaran metode drill. Siklus I dimulai dengan perencanaan seperti menentukan materi yang akan menjadi pokok bahasan pada pertemuan selanjutnya, menyusun rencana pelaksanaan 
pembelajaran (RPP) yang sesuai dengan pembelajaran metode drill, menyiapkan media pembelajaran berupa lembar kegiatan yang akan dikerjakan oleh tiap-tiap kelompok, menyusun instrument penilaian dan kunci jawaban, tes yang terdiri dari tes tulis yang berupa soal-soal pilihan ganda sebanyak 20 soal dengan empat option untuk mengetahui hasil belajar siswa tiap-tiap siklus. Pada tahap pelaksanaan, peneliti melaksanakan semua perencanaan pembelajaran yang telah disusun. Secara garis besar pelaksanaan proses pembelajaran adalah: (1) melakukan kegiatan pembiasaan seperti mengucapkan salam, berdoa, mengabsen, apersepsi, serta menjelaskan tujuan pembelajaran, (2) siswa terlebih dahulu dibekali dengan pengetahuan secara teori, sesuai dengan bahan ajaran yang akan diterapkan dengan metode pembelajaran drill, (3) selanjutnya memberikan materi dengan singkat, (4) memberikan contoh latihan soal sebelum diberikannya latihan tentang materi pembelajaran yang telah diberikan, (5) memberikan latihan soal-soal tentang materi yang telah diberikan, kemudian dikerjakan oleh siswa, dengan bimbingan guru, (6) mengoreksi dan membetulkan kesalahan-kesalahan latihan yang dilakukan oleh siswa, (7) siswa diharuskan mengulang kembali latihan untuk mencapai gerakan otomatis yang benar, (8) pengulangan yang ketiga kalinya atau terakhir, guru melakukan evaluasi hasil belajar siswa, dengan lembar tes. Evaluasi dilakukan pada saat melakukan kegiatan yang ketiga kalinya, (9) memberikan evaluasi kepada seluruh siswa dengan memberikan latihan soal kepada seluruh siswa untuk mengetahui pemahaman siswa.

Evaluasi diberikan di akhir siklus I, kegiatan ini dimaksudkan untuk mengukur penguasaan hasil belajar siswa setelah peneliti menerapkan model pembelajaran metode drill. Tes hasil belajar diberikan kepada siswa dengan bentuk tes pilihan ganda dengan soal sebanyak 20 soal dengan empat pilihan jawaban. Dengan memerhatikan hasil belajar yang telah diperoleh pada tahap evaluasi, dilakukan perbandingan antara nilai hasil belajar dan indikator keberhasilan. Berdasarkan nilai tersebut, ditentukan dan direncanakan kegiatan pembelajaran pada tahap selanjutnya. Pengumpulan data ini dilaksanakan selama pelaksanan tindakan dengan teknik tes. Tes digunakan untuk mengumpulkan data yang berupa nilai-nilai siswa, sehingga diketahui peningkatan hasil belajar siswa setelah diterapkannya model pembelajaran metode drill dengan menggunakan tes pilihan ganda sebanyak 20 soal dengan empat pilihan option. Penelitian ini menggunakan teknik analisis data secara kuantitatif. Analisis kuantitatif digunakan untuk mendeskripsikan hasil belajar siswa dalam hubungannya dengan penguasaan materi pembelajaran. Analisis deskriptif kuantitatif yaitu dengan mencari rata-rata nilai siswa, daya serap, dan ketuntasan belajar siswa.

\section{HASIL DAN PEMBAHASAN}

\section{Hasil}

Berdasarkan hasil penelitian dari prasiklus, siklus I, dan siklus II, dapat digambarkan rekapitulasi hasil pembelajaran seperti Tabel 01 . Hasilnya menunjukkan bahwa nilai rata-rata kelas mengalami peningkatan dari 54 pada hasil belajar prasiklus menjadi 65 pada siklus I, kemudian meningkat menjadi 72 pada siklus II. Sedangkan nilai daya serap siswa juga mengalami peningkatan dari 54\% pada prasiklus meningkat menjadi $65 \%$ pada siklus I, kemudian meningkat menjadi $72 \%$ pada siklus II. Ketuntasan belajar juga mengalami peningkatan dari $30 \%$ pada hasil belajar prasiklus, naik menjadi $60 \%$ pada siklus I, kemudian meningkat menjadi $100 \%$ pada siklus II. Hasil analisis pada setiap siklus menunjukkan bahwa nilai rata-rata kelas mengalami peningkatan dari 54 pada hasil belajar prasiklus menjadi 65 pada siklus I, kemudian meningkat menjadi 72 pada siklus II. Jadi, penerapan metode drill dapat meningkatkan hasil belajar matematika siswa kelas IV SD Negeri 2 Telaga.

Tabel 1. Perkembangan Hasil Belajar

\begin{tabular}{lrrrr}
\hline \multicolumn{1}{c}{ Uraian } & Prasiklus & \multicolumn{1}{c}{ Siklus I } & \multicolumn{1}{c}{ Siklus II } & Peningkatan \\
\hline Jumlah & 540 & 645 & 720 & 75 \\
Rata-rata & 54 & 65 & 72 & 7 \\
Daya serap & $54 \%$ & $65 \%$ & $72 \%$ & $7 \%$ \\
Ketuntasan belajar & $30 \%$ & $60 \%$ & $100 \%$ & $40 \%$ \\
\hline
\end{tabular}

\section{Pembahasan}

Hasil penelitian menunjukkan bahwa penerapan metode drill dapat meningkatkan hasil belajar matematika. Hal ini terjai karena pembelajaran dengan metode drill yang dikembangkan memerhatikan beberapa hal berikut. Pertama, bahan pelajaran yang diberikan dalam suasana yang sungguh-sungguh akan lebih kokoh tertanam dalam daya ingatan murid, karena seluruh pikiran, perasaan, kemauan dikonsentrasikan pada pelajaran yang dilatihkan. Peningkatan kemampuan siswa dalam memahami materi ditentukan juga oleh metode yang digunakan saat proses pembelajaran (Erlinda, 2016; Jauhariyah 
\& Dardiri, 2017). Kedua, siswa dapat mempergunakan daya pikirannya dengan bertambah baik. Dengan pengajaran yang baik, maka anak didik akan menjadi lebih teratur, teliti, dan mendorong daya ingatnya. Adanya metode tersebut membuat siswa lebih terlatih menghadapi berbagai macam model soal matematika, sehingga siswa lebih bersemangat dalam mempelajari materi yang diajarkan oleh guru (Fransiska et al., 2019; Jaelani \& Aisyah, 2017). Ketiga, adanya pengawasan, bimbingan dan koreksi yang segera serta langsung dari guru, memungkinkan murid untuk melakukan perbaikan kesalahan saat itu juga. Hal ini dapat menghemat waktu belajar di samping juga murid langsung mengetahui prestasinya. Oleh karena itu, metode drill dapat digunakan dalam proses pembelajaran untuk meningkatkan hasil belajar matematika.

Peningkatan hasil belajar saat kegiatan belajar melalui metode drill menunjukkan bahwa siswa lebih termotivasi saat mereka terlibat secara langsung dalam kegiatan belajar-mengajar. Metode drill menekankan peran siswa untuk terlibat secara langsung dalam membangun suasana yang tepat dalam proses pembelajaran agar muncul suatu kondisi, sehingga siswa memiliki pengetahuan dan kecakapan yang mumpuni. Metode Drill banyak dilakukan dalam pelaksanaan pembelajaran karena memberikan pengaruh yang baik dalam pembelajaran (Fransiska et al., 2019). Selain itu, dengan memberikan pola drill untuk mengerjakan soal-soal yang diberikan, siswa tertarik untuk belajar. Setiap soal yang diberikan harus dikerjakan dengan pola drill dan soal yang diberikan kepada siswa secara berulang-ulang dengan variasi soal yang beragam. Dalam pengerjaan soal juga ada penerapan drill dengan tahap-tahap pengerjaan soal. Dengan memerhatikan aspek-aspek, menunjukkan bahwa metode drill yang dikembangkan dapat menumbuhkan suasana yang bebas, ceria, gairah, dan kondusif sehingga tujuan penelitian ini yakni peningkatan hasil belajar siswa dapat terwujud di akhir siklus II.Temuan ini diperkuat dengan penelitian sebelumnya yang menyatakan metode drill dapat meningkatkan hasil belajar siswa (Erlinda, 2016; Jaelani \& Aisyah, 2017). Selain itu metode drill dapat meningkatkan kemampuan pemecahan masalah siswa (Fransiska et al., 2019; Jauhariyah \& Dardiri, 2017). Penerapan metode drill dapat meningkatkan keterampilan menulis (Natalita et al., 2019; Putri et al., 2019). Berdasarkan pembahasan, penerapan metode drill untuk meningkatkan hasil belajar matematika telah mencapai target seperti yang ditetapkan dalam indikator keberhasilan dalam penelitian ini. Namun, dalam penerapannya, metode ini membutuhkan waktu yang lama. Implikasi penelitian ini diharapkan dapat membantu siswa dalam proses pembelajaran, sehingga dapat meningkatkan hasil belajar matematika siswa.

\section{SIMPULAN}

Penerapan metode drill dapat meningkatkan hasil belajar matematika pada siswa kelas IV. Metode drill dapat membantu guru dalam mengatasi kesulitan belajar yang ditemui di kelas. Metode Drill dapat digunakan sebagai alternatif dalam proses belajar mengajar serta penelitian selanjutnya, yaitu agar dapat mengkaji masalah dengan jangkauan yang lebih luas dan mencoba menggunakan model-model pembelajaran lain untuk memaksimalkan berbagai aspek dalam pembelajaran matematika.

\section{DAFTAR RUJUKAN}

Alfiyah, Z. N., Hartatik, S., Nafiah, N., \& Sunanto. (2021). Analisis Kesulitan Belajar Matematika secara Daring bagi Siswa Sekolah Dasar. Jurnal Basicedu, 5(5), 3158-3166. https://doi.org/10.31004/basicedu.v5i5.1297.

Arianti, Wiarta, \& Darsana. (2019). Pengaruh Model Pembelajaran Problem Posing Berbantuan Media Semi Konkret terhadap Kompetensi Pengetahuan Matematika. Jurnal Ilmiah Sekolah Dasar, 3(4). https://doi.org/10.23887/jisd.v3i4.21765.

Arikunto, S. (2010). Penelitian Tindakan Kelas. Bumi Aksara.

Buyung, B., \& Nirawati, R. (2018). Pengaruh Karakter Kerja Keras terhadap Kemampuan Literasi Matematis Siswa Melalui Model Discovery Learning. JPMI (Jurnal Pendidikan Matematika Indonesia), 3(1), 21-25. https://doi.org/10.26737/jpmi.v3i1.519.

Crismono, P. C. (2017). Pengaruh Outdoor Learning terhadap Kemampuan Berpikir Kritis Matematis Siswa. Jurnal Pendidikan Matematika Dan Sains, 5(2), 106 - 113. https://doi.org/10.21831/jpms.v5i2.15482.

Dewi, N. A. K., Trisnawati, T., \& Kristina, M. (2020). The Drill Method with Realistic Approach to Improve Learning Outcomes of Descriptive Statistics in Higher Education. JINOP (Jurnal Inovasi Pembelajaran), 6(1), 215 - 226. https://doi.org/10.22219/jinop.v6i2.13010.

Dini, M., Wijaya, T. T., \& Sugandi, A. I. (2018). Pengaruh Self Confidence terhadap Kemampuan Pemahaman Matematik Siswa SMP. JURNAL SILOGISME : Kajian Ilmu Matematika Dan Pembelajarannya, 3(1), 1. https://doi.org/10.24269/js.v3i1.936. 
Erlinda, Y. (2016). Upaya Meningkatkan Hasil Belajar Matematika Perkalian Bersusun ke Samping Melalui Metode Drill Bagi Anak Tunagrahita Ringan. Jurnal Konseling Dan Pendidikan, 4(3), 18 - 23. https://doi.org/10.29210/187\%y.

Fransiska, C., Masykur, R., \& Putra, F. G. (2019). Analisis Kemampuan Pemecahan Masalah Matematis: Dampak Metode Drill ditinjau dari Gaya Belajar. Desimal, 2(2), 131 - 140. https://doi.org/10.24042/djm.v2i2.4147.

Jaelani, A., \& Aisyah, S. (2017). Pengaruh Metode Drill terhadap Hasil Belajar Matematika Materi Perkalian pada Siswa Kelas III MIN Kota Cirebon. Al Ibtida: Jurnal Pendidikan Guru MI, 4(1), 87 - 96. https://doi.org/10.24235/al.ibtida.snj.v4i1.1472.

Jauhariyah, D., \& Dardiri. (2017). Pengaruh Penggunaan Metode Drill pada Materi Kalor terhadap Hasil Belajar Fisika Siswa. Jurnal Ilmiah Pendidikan Fisika Al-Biruni, 6(1), 37 - 45. https://doi.org/10.24042/jpifalbiruni.v6i1.907.

Khaerunnisa, E., \& Pamungkas, A. S. (2018). Pengembangan Instrumen Kecakapan Matematis dalam Konteks Kearifan Lokal Budaya Banten pada Materi Bangun Ruang Sisi Datar. Kreano Jurnal Matematika Kreatif-Inovatif, 9(1), 17 - 27. https://doi.org/10.15294/kreano.v9i1.11210.

Khairani, B. P., \& Roza, Y. (2021). Analisis Kemampuan Pemahaman Konsep Matematis Siswa Kelas XI SMA/MA pada Materi Barisan dan Deret. Jurnal Cendekia: Jurnal Pendidikan Matematika, 5(2), 1578-1587. https://doi.org/10.31004/cendekia.v5i2.623.

Kusumah, R. G. T., Walid, A., Pitaloka, S., Dewi, P. S., \& Agustriana, N. (2020). Penerapan Metode Inquiry sebagai Usaha untuk Meningkatkan Hasil Belajar IPA pada Materi Penggolongan Hewan di Kelas IV SD Seluma. Jurnal Pendidikan Matematika Dan IPA, 11(1), 142-153. https://doi.org/10.26418/jpmipa.v11i1.34708.

Muhammad, I. (2020). Pengaruh Perkuliahan Daring terhadap Kemandirian Belajar Mahasiswa Prodi Pendidikan Matematika Universitas Malikussaleh. Jurnal Ilmiah Pendidikan Matematika Al Qalasadi, 4(1), 24-30. https://doi.org/10.32505/qalasadi.v4i1.1567.

Natalita, R. K., Situngkir, N., \& Rabbani, S. (2019). Meningkatkan Keterampilan Menulis Tegak Bersambung dengan Menggunakan Metode Drill pada Siswa kelas 1 SD. Journal of Elementary Education, 02(January), 18-25. https://journal.ikipsiliwangi.ac.id/index.php/collase/article/download/3084/804.

Netriwati, N. (2018). Penerapan Taksonomi Bloom Revisi untuk Meningkatkan Kemampuan Pemahaman Konsep Matematis. Desimal: Jurnal Matematika, 1(3), 347-352. https://doi.org/10.24042/djm.v1i3.3238.

Ningsih, Y. L. (2016). Kemampuan Pemahaman Konsep Matematika Mahasiswa melalui Penerapan Lembar Aktivitas Mahasiswa (LAM) Berbasis Teori APOS pada Materi Turunan. Edumatica : Jurnal Pendidikan Matematika, 6(1). https://doi.org/10.22437/edumatica.v6i01.2994.

Pambudi, D. S. (2007). Berbagai Alternatif Model dan Pendekatan dalam Pembelajaran Matematika. Jurnal Pendidikan Matematika, 1(2), 39-45. https://doi.org/10.22342/jpm.1.2.812.

Prasasti, D. E., Koeswanti, H. D., \& Giarti, S. (2019). Peningkatan Keterampilan Berpikir Kritis dan Hasil Belajar Matematika melalui Model Discovery Learning di Kelas IV SD. Jurnal Basicedu, 3(1), 174179. https://jbasic.org/index.php/basicedu/article/view/113.

Prasojo, T. (2016). Peningkatan Aktivitas dan Hasil Belajar Matematika dengan Metode Tutor Sebaya pada Siswa Kelas X IPA 7 Materi Trigonometri SMA Negeri 1 Kudus. Kreano: Jurnal Matematika Kreatif Inovatif, 7(1), 31-40. https://doi.org/10.15294/kreano.v7i1.5049.

Putri, F. W., Hartati, T., \& Mulyasari, E. (2019). Penerapan Metode Drill untuk Meningkatkan Keterampilan Menulis Permulaan Siswa Kelas Ii SD. Jurnal Pendidikan Guru Sekolah Dasar, 4(3), 155-166. https: //doi.org/10.17509/jpgsd.v4i3.22916.

Sulastri, A. (2016). Penerapan Pendekatan Kontekstual dalam Pembelajaran Matematika untuk Meningkatkan Pemahaman Konsep Matematis Siswa Sekolah Dasar. Jurnal Pendidikan Guru Sekolah Dasar, 1(1), 156-170. https://doi.org/10.17509/jpgsd.v1i1.9068.

Unaenah, E., Setyadi, arif rahman, Sari, Putri Widiya, El-Abida, S. F., Agustina, N., Fauziah, S., \& Leonardho, R. (2020). Pengembangan Aplikasi Pembelajaran Matematika tentang Pengukuran Waktu, Panjang dan Berat untuk Sekolah Dasar. Jurnal Edukasi Dan Sains, 2(1), 192-201.

Yanni, M. H. (2018). Meningkatkan Aktivitas dan Hasil Belajar Matematika melalui Strategi Pembelajaran TAPPS Berbasis Pendekatan (STEM). Jurnal Pendidikan Matematika (JUDIKA EDUCATION), 1(2), 117-125. https://doi.org/10.31539/judika.v1i2.373. 